\title{
Party Institutionalization AND THE REMOVAL of Presidential Term Limits in Latin America*
}

\author{
Institucionalización de partidos y la eliminación de los límites \\ a los mandatos presidenciales en América Latina
}

\author{
KAREL KOUBA \\ University of Hradec Králové
}

\begin{abstract}
An explanation of the recent wave of constitutional changes in favor of more permissive reelection rules in Latin America is presented based on a principal-agent model of intraparty relations within the presidential party. The theoretical model suggests causal mechanisms through which institutionalized presidential parties constrain the decision to scrap term limits. The theoretical implications are tested using both quantitative and qualitative evidence. Results from logistic regression suggest that the likelihood of removing term limits in Latin American countries (1990-2013) significantly declines with the level of presidential party institutionalization. Case study evidence illustrates the operation of the theoretically-derived causal mechanisms.
\end{abstract}

Key words: Presidential reelection, party institutionalization, term limits, comparative politics, Latin America.

\begin{abstract}
RESUMEN
El objetivo de este artículo es explicar la reciente ola de cambios constitucionales a favor de normas más permisivas de reelección en América Latina a partir del modelo principal-agente basado en las relaciones intrapartidarias dentro del partido del Presidente. El modelo teórico plantea mecanismos causales por los que los partidos presidenciales institucionalizados restringen la decisión de eliminar los límites del mandato. Las implicaciones teóricas del modelo se examinan con evidencia cuantitativa y cualitativa. Los resultados de la regresión logística sugieren que la probabilidad de evadir los límites al mandato presidencial en los países de América Latina (1990-2013) disminuye significativamente con el nivel de institucionalización del partido del Presidente. Estudios de casos ilustran el funcionamiento de los mecanismos causales derivados del modelo teórico.
\end{abstract}

Palabras clave: Reelección presidencial, institucionalización de los partidos, límites de mandato, política comparada, América Latina.

* Acknowledgements: The article was written as a part of the research grant by the Czech Science Foundation (Grantová Agentura České Republiky) Volební pravidla a politická nestabilita v Latinské Americe (Electoral Rules and Political Instability in Latin America, code GPP408/12/P357). I thank the three anonymous referees for their helpful comments. 


\section{INTRODUCTION}

What are the forces driving the removal of the bans on immediate reelection in Latin America? Those Presidents facing constitutional reelection bans at the beginning of their terms have been able to do away with them eleven times since 1990, allowing themselves immediate reelection. ${ }^{1}$ Yet many other Latin American countries have been immune to the reelectionist fever maintaining their constitutional proscriptions on reelection or even making the rules more restrictive. ${ }^{2}$ The article aims to provide explanation of one of the most controversial type of constitutional reform in Latin America, namely the elimination of term limits by Presidents who began their mandate with a ban on immediate reelection. ${ }^{3}$ The argument presented here focuses on the role of intraparty dynamics that shape the decision to evade term limits from a principal-agent theoretical perspective. Where political parties act as principals delegating presidential nominations to their agents, they are also likely to limit their ambitions at overstaying their presidential mandate. The present article aims to contribute to both the literature on the causes and consequences of presidential re-election rules and the literature on the intraparty principal-agent relationships in presidential regimes by approaching two puzzles.

First, while case studies suggest that presidential party weakness is crucial for understanding the elimination of term limits in Latin America (Molina, 2009; Corrales, 2009), the question has either not been approached in comparative analyses of the determinants of reelection rule change (Baturo, 2010), or presidential party institutionalization was found to play no role in another comparative analysis of the decision to remove or conversely institute constitutional term limits in Latin America (Negretto, 2013: 93). The theoretical model proposed here aims to fill this lacuna and systematic evidence is provided. Concomitantly, the article proposes causal mechanisms which drive the decision to scrap or maintain term limits.

The second puzzle is theoretical. A principal-agent model of the relations between the Presidents and their parties suggests that parties in presidential regimes provide few checks on their presidents and are unable to hold them accountable (Samuels, Shugart 2010). Latin American Presidents should therefore be effectively insulated from party politics which should not matter for their survival in office. If this were the case,

1 They are the following cases: Peru 1993, Argentina 1994, Peru 1996, Brazil 1997, Nicaragua 2009, Venezuela 1999, Dominican Republic 2002, Colombia 2005, Ecuador 2008, Venezuela 2009, and Bolivia 2009. In ten of these eleven cases Presidents ran and won immediate reelection. Only Hipólito Mejía of the Dominican Republic lost in the 2004 bid for reelection.

2 There have also been reforms in the opposite direction, prohibiting immediate reelection: Colombia 1991, Paraguay 1992, Nicaragua 1995, Dominican Republic 1994, and Peru 2000. However, of these five reforms three have been overturned later by instituting more permissive rules (Dominican Republic, Colombia and Nicaragua), leaving only two such reforms (Peru and Paraguay) operative. Making the reelection rules more permissive constitutes the dominant trend in Latin America.

3 A similar concept of term "term limit evasion" has been presented in the literature (Ginsburg et al., 2011) but is not used here because "evasion" may misleadingly refer to criminal action. Elimination of term limits refers here to such constitutional reform that enables a sitting President to run for immediate reelection. Elimination of term limits does not refer to enabling unlimited reelection (eliminating all term limits), but to allowing at least one immediately subsequent term. 
presidential parties should not be expected to exercise much effect on the decision to scrap presidential term limits. This puzzle is approached by arguing that whether principals (parties) are capable of holding their agents (Presidents) accountable depends on their level of institutionalization. Institutionalized parties generate such structures of opportunities and provide such constraints that reduce the likelihood of presidents seeking and securing reelection rule change. At the other extreme are underinstitutionalized parties ('personalistic vehicles') in which the principal-agent relationship is reversed. These parties are effectively created and act as agents of the president.

Understanding the origins of the reelection rule change may also shed some light on the normative debate regarding the appropriateness of term limits which is not reproduced here (for reviews of the arguments see Carey, 2003; Ginsburg et al., 2011) as well as on the emerging literature that has sought to uncover the political consequences of presidential reelegibility in Latin America (Corrales and Penfold, 2014; Penfold, Corrales and Hernández, 2014). Understanding whether term limits shape the democratic process positively or negatively is inexorably linked to the manner in which rules governing them are instituted. If the origins of reeligibility lie in open negotiations between the president and the opposition, are complemented by power concessions and preserve ample space for the opposition, then reelection may serve to enhance democracy; if on the other hand term limit evasion is pursued unilaterally by the President without respect to other political actors and institutions, then presidencies become more authoritarian (Carey, 2003: 131; Del Campo, 2009: 7). Moreover, drives for term limit removal have political importance in their own right as they may serve as incentive for the unification and mobilization of the opposition as in Paraguay in 2006, or as a pretense for military ouster of the president as in Honduras in 2009.

It is for these reasons that this article delves into the issue of the origins of the recent wave of reelectionism in Latin America. First, a theoretical model which views weak party institutionalization as central to term limit manipulation is developed and alternative theories are discussed. The second section operationalizes the model and assesses its validity using quantitative evidence from Latin American presidencies between 1990 and 2013. Third, qualitative evidence corroborating the operation of the theorized causal mechanisms is provided by examining cases of both successful and unsuccessful term limit evasion.

\section{PARTY INSTITUTIONALIZATION AND TERM LIMIT REMOVAL}

Under what conditions do Presidents' parties consent or contrarily block their President's bid for overstaying their initial mandate? The theoretical model departs from the observation that intraparty competition and party organization of the President's party is crucial for understanding term limit elimination across Latin America. The intraparty dynamics are conceptualized as a principal-agent relationship between the president and his party. Principal-agent relations imply a hierarchical relationship running from the principal who delegates conditional authority to the agent. The agent in turn is 
supposed to be accountable, meaning that the principal has the right to withdraw the conditionally delegated authority (Moreno et al., 2003: 83). There are a number of ways in which the delegated authority may be withdrawn from political agents, including their outright dismissal or reducing the scope of their authority. It may also mean "refusing to renew a delegation relationship that has a fixed endpoint" (Moreno et al., 2003: 83). This last point is crucial for understanding the dynamics of term limit constitutional reform under presidentialism. Promoting or consenting (or not) to a term extension can be conceptualized as a principal-agent relationship, whereby presidential parties (as principals) may or may not renew delegation to the President (agent). ${ }^{4}$

However, parties do not always act as principals with the capacity to rein in their presidential agents. In fact, a crucial contribution to the principal-agent perspective on political delegation is the observation that party structures vary in predictable ways according to types of constitutional structures and that presidentialism inhibits parties' ability to hold their Presidents accountable (Samuels and Shugart, 2010). On the contrary, the fusion of powers defining parliamentary regimes produces parliamentarized parties with a simple chain of delegation running from voters to parties to party leaders and imposes mutual dependence within parties (Samuels and Shugart, 2010: 37). While the heads of Executive (Prime Ministers) are easily held accountable by their own parties under parliamentarism, presidential regimes generate such parties in which Presidents cease to be accountable to their parties due to the separate origin and survival of the executive and legislative branches. Presidentialized parties are split into Executive and Legislative parts with twin and potentially competing goals (winning legislative and presidential elections), their presidents may pursue policies different from those of their parties without fear of dismissal, and possess a definite power advantage over their parties (Samuels and Shugart, 2010: 38). In presidential regimes characterized by separation of purpose, the principal-agent relationship becomes reversed by making the party hostage to the President (Samuels and Shugart, 2010: 111). This situation results from the fact that parties in presidential regimes lack instruments of internal accountability that could threaten to deselect the president, and using the extreme option of impeachment is rare and risky for the presidents' parties themselves. Presidents become effectively insulated from the vicissitudes of intraparty politics which bears no importance to their survival in office beyond the nomination stage of the electoral process (Samuels and Shugart, 2010: 121).

While this theoretical argument presents a compelling account by distinguishing general party types among parliamentary, semi-presidential and presidential regimes, it is less useful in explaining the great variation in party organization that characterizes Latin American presidential democracies (Roberts, 2012: 50). The variety of Latin American parties encompasses strongly institutionalized, bureaucratic and hierarchical party types as well as personalistic platforms with fluid membership and weak institutionalization.

Such an accountability relationship between Presidents and their parties is not included in models emphasizing that parties cannot deselect their Presidents in presidential democracies (Samuels and Shugart, 2010: 108), but could be expected to operate for reasons discussed below. 
Given such variety, there are limits to the generalization that the principal-agent relationship is reversed under presidentialism. In particular, the level of party institutionalization intervenes in the degree of insulation of party leaders from their parties. In highly institutionalized parties individuals depend on their party organization in terms of their nomination, election (and governing), while non-institutionalized parties contrarily depend on the permanence in power of their leader for their existence (Molina, 2009: 155). In non-institutionalized or under-institutionalized party system settings political leaders become autonomous from and unaccountable to their parties which serve as their personalistic instruments (Sánchez, 2009: 502). This both contributes to policy switching away from their party platforms, or to the betrayal of electoral mandates (Stokes, 1997), and generates conditions for Presidents to seek to extend their tenure by eliminating term limits (Molina, 2009: 155; Corrales, 2009: 70). As parties become more institutionalized, it is easier for them to hold their presidential agents to accounts in terms of policy or deselection, while a lack of institutionalization implies that the delegation relationship is fully reversed.

Consequently, the extent to which the principal-agent relationship is reversed in presidential regimes should be related to presidential party institutionalization, and this should in turn influence the opportunities for scrapping term limits. Three main causal mechanisms can be identified through which the degree of party institutionalization intervenes in the principal-agent relationship between presidents and their parties.

First, a President's party institutionalization alleviates the pressure to evade term limits because long-lived, institutionalized parties foster longer time-horizons to their members by providing structure to inter-generational conflicts within parties. Viewing parties as sequences of politically active candidates in different time periods, Alesina and Spear (1988) find that even party politicians at the closing of their political careers follow "far-sighted" policies rather than maximizing their short run benefits at the expense of their party. This, of course, hinges on them assuming that their party will not die soon (i.e. is infinitely lived) and that their future access to the presidential office is open. Young members are assumed to work hard for the party in exchange for the possibility of acceding to high ranking political positions in the future (Alesina and Spear, 1988). The overlapping generations party model keeps the party unified and prevents the rise of personalistic leadership styles by reducing the potential for intra-party conflicts based on personal ambition.

Under-institutionalized parties which are born and die quickly are expected to focus their party members' vision on the short run (Stokes, 2001: 120). Their composition based on a single generation of militants is unlikely to develop that sort of intergenerational checks on personal ambitions of their presidents. Young members in parties that cannot be expected to last into the future have little reason to invest in constraining the behavior of current officeholders (Stokes, 2001: 115). Rather, the lack of a long-term vision of political careers facilitates the acceptance of short-term benefits in exchange for their acquiescence to personalistic political projects of their party leaders. Scrapping term limits by a President blocks the advance of younger cohorts of party members to political office. Such personalistic projects are, however, unlikely to succeed where parties are expected to last beyond the political career of a specific 
leader. Last but not least, long-established parties are likely to take care of the future career prospects of their non-reelegible out-going Presidents which smoothens their stepping down and makes the transfer of presidential power a less costly endeavor for the presidents. Presidents elected on personalistic platforms are more likely to resort to extending their stay in power as their parties lose political relevance once removed from the spoils of presidential office.

Second, party institutionalization prevents term limit elimination because it increases the supply of alternative politicians within the party with a potential to run for President in the future and because it gives rise to powerful intra-party veto players capable of blocking the Presidents' continuation in power. The latter is facilitated by the existence of factionalism. The term faction refers to 'any relatively organized group that exists within the context of some other group and which (as a political faction) competes with rivals for power advantages within the larger group of which it is a part' (Beller and Belloni, 1978: 419 cf. Randall and Svåsand, 2002: 20). This broad definition allows for the existence of a variety of motives for factionalism, including programmatic or leadership struggles. Whereas part of the literature views factionalism as inimical to party institutionalization, more recent accounts emphasize compatibility between both. Factionalism may enhance party adaptability because it smoothens transitions in party leadership as in the Japanese Liberal Democratic Party or former Italian Christian Democrats (Randall and Svåsand, 2002: 20). It may help create more integrated parties because it promotes intra-party cooperation while preserving distinct subparty identities (Boucek, 2009: 479). Even in situations where factionalism generates intraparty conflict rather than consensus, it may widen voter choice and thus the party's electoral strength, it can improve intraparty democracy and provide structure for internal power-sharing (Boucek, 2009: 479). There is case study evidence to suggest that the support for the absolute proscription on reelection in Latin America stems from the factionalism with the presidential party as the potential for party splits is present and term limits could facilitate the alternation of power among different groups (Negretto, 2013: 184). Similarly, comparative evidence form three African nations suggests that the ability of individuals or groups within ruling parties to break from their leadership and challenge their executives facilitated by the existence of factionalism is crucial for explaining the non-adoption of reelection amendments (VonDoepp, 2005).

Third, party institutionalization is antithetical to highly personalistic political projects which may result in attempts to scrap term limits for their continuation in power. Party organizations are not subordinated to the interests of a few ambitious leaders and do not serve as personal instruments of specific leaders (Huntington, 1968; Janda, 1980; Mainwaring and Torcal, 2006). Institutionalized parties broaden and diversify the elite recruitment process, socialize politicians into democratic politics and prevent the rise of political outsiders (Levitsky and Cameron, 2003: 4-5). The experience gained through gradual ascension through the ranks of an institutionalized party inculcates democratic values and fosters intraparty democracy. Conversely, the weakness of many Latin American parties has opened the way for strong personal leaders who have become effectively autonomous of their party organizations which in turn become heavily 
dependent on the permanence in office of their leaders (Molina, 2009: 155). Weak noninstitutionalized parties fail to serve as checks on presidential power because their Presidents wield a disproportionate power advantage, while strong parties are able to constrain the behavior of their presidents including their attempts to scrap term limits (Corrales, 2009: 70). Furthermore, the personalization of politics linked to party system deinstitutionalization creates the perception among both the rank and file and the voters that the continuation of policies that have benefitted them depends on the continuation in power of the incumbent President (Molina, 2009: 155). As such, deinstitutionalization of political parties has become one of the principal causes of Presidents seeking to extend their tenure through scrapping term limits (Molina, 2009: 155).

The theoretical model proposes that the extent to which the intraparty principal-agent relationship is reversed within the president's party explains the likelihood of term limit elimination, and that this reversal is related to party institutionalization. The observable implications include the principal hypothesis of the article that maintains that the likelihood of a President scrapping his term limit for a consecutive term is greatest when the President's party is a newly-created personalistic vehicle devoid of organizational autonomy, but declines with the degree of the party's institutionalization. On the qualitative side, the argument implies that reelection drives should be associated with parties/platforms where the president controls access to party nominations, party organizations are fluid and subject to the President's decisions and popularity. Conversely term limit evasion should be prevented by parties that are organizationally "thick", long-lived, possess an autonomous party organization and feature interparty veto-players capable of challenging the President.

\section{ALTERNATIVE THEORIES}

Despite the recent interest in Latin American reelection reforms, we know surprisingly little about the causes of this phenomenon. Four main general comparative approaches to explaining reelection rule change can be identified. First, some comparative explanations emphasize the importance of party system structure for constraining or promoting reelection rule changes (Buquet, 2007; Negretto, 2013). Negretto (2013) views party systems at the time of constitutional change as one of the key structures that shape electoral expectations and relative power of constitution reformers, which in turn inform their institutional preferences. Although his two-level theory of constitutional change allows for cooperative causes of reelection rule change (where the emphasis is placed on the collective benefits perceived by constitution designers), this choice is also largely conditioned by partisan strategic calculations reflecting their electoral strength (Negretto, 2013: 63). In contrast to smaller parties, members of dominant and electorally strong parties are more likely to favor more permissive reelection rules because their prospects of winning the presidency are higher. In Latin American comparison, the presence of a fragmented reform coalition in the constituent body favors the adoption of more restrictive reelection rules, and the presence of a dominant party generates more permissive rules (Negretto, 2013: 93). 
Second, more general comparative arguments have identified different sets of factors. Baturo (2010) in a global comparison puts forward an actor-centered model in which term limit evasion is explained by the individual presidents' calculation of the stakes of stepping down and the political constraints that prevent him/her from scrapping term limits. The constraints component of this model concerns the capacity of the president to confront other political actors and change the constitution (Baturo, 2010: 643). Presidents whose discretion is constrained by powerful veto players, constitutional or political, will be less likely to overstay their mandates. Latin American presidencies differ markedly in the powers vested in the president signaling that the less powerful presidents would face a more difficult situation when negotiating and pushing for a term limit change. Many of the attempts at scrapping term limits have been deferred to courts especially when presidents lack sufficient parliamentary support to make the necessary constitutional change (Martínez-Barahona, 2012). Presidents facing less independent judiciaries should therefore be more likely to succeed in their bid for permitting reelection.

Assuming that the primary motivation of politicians is to remain in office, the stakes model predicts that as the value of holding office increases, so does the temptation to overstay the initial term (Baturo, 2010: 640-641). The value of office is greater in poorer and more unequal societies in part because inequality implies a higher relative loss of assets from redistribution should the president decide to step down. Also, the value of office is greater in countries with plentiful opportunities for extraction of rents from the economy. Here, the large size of the public sector is indicative of the value of office because it increases opportunities for rent-seeking through large-scale patronage and clientelism, and thus increases the stakes of leaving office if the ruler relinquishes control over the economy (Baturo, 2010: 641). Similarly, in a post-communist context, Guliyev (2009) argues that the extent of rents accruing from natural resources is responsible for doing away with term limits by the presidents. Rentier economies undermine democratic prospects in general (Ross, 2001), and scrapping term limits is just one of the institutional manifestation of authoritarian tendencies. Natural resource rents provide the presidents with the possibility to create and maintain patronage and clientelist networks which are used to achieve political acquiescence (Guliyev, 2009). The stakes of holding on to power by the President and his inner circle are also higher because of the benefits from windfall gains and because of the fear of uncovering corrupt behavior. A decision to eliminate term limits is therefore driven by the need to sustain a rentier system with the President as its main guarantor, and whose functioning could be put to risk by a succession crisis had term limits existed (Guliyev, 2009).

Third, institutions are "sticky" in the sense that previous institutional arrangements may severely constrain the choice available to reformers. More restrictive reelection rules in place at the beginning of a President's term may make it more costly for Presidents to evade term limits due to inertial effects of institutions (Negretto, 2013: 87). The most restrictive rule -an absolute proscription on reelection- has become entrenched and accepted by political actors in the politics of such countries as Mexico where the principle of non-reelection has acquired a strong symbolic importance since the Mexican Revolution (Linz, 1994: 16). Strategic calculations of outgoing Presidents may also be influenced by 
the pre-existing rule. Those Presidents who face an intermediately restrictive reelection rule (a possibility of reelection after one or two terms) may consider the possibility of future reelection a less costly means of winning the presidency than a risky attempt to constitutionally engineer immediate reelection. The recent proliferation of Latin American ex-Presidents running for and winning office (Corrales, 2008) attests to the possibility that such calculation may indeed take place. Finally, the decision of the President to eliminate term limits and allow himself/herself to overstay the initial term will be more likely in situations where presidents feel comfortable actually winning the immediate reelection. High presidential popularity is therefore important as such Presidents are more likely to be confident in winning another term as well as defeating possible opponents in their quest to eliminate term limits do so (Baturo, 2010: 643). The effect of approval rates on the elimination of term limits should also be viewed in the context of party institutionalization (Corrales, 2009: 71). When a President is popular, even strong or institutionalized parties may support the reelection of the President (or the removal of term limits) because by doing so the party increases its chances to remain in power. ${ }^{5}$ When estimating the effect of party institutionalization on the likelihood of eliminating term limits it is therefore necessary to control for a measure of presidential popularity.

\section{QUANTITATIVE ANALYSIS}

There are two main approaches to sample selection when modeling the determinants of the choice of reelection rules. Each has its advantages and drawbacks. The first approach compares only cases where any kind of reelection rule change occurred and asks about the direction of such constitutional reform (whether a more or less restrictive reelection reform was put in place) (e.g. Buquet, 2007; Negretto 2013). For the second approach, which is adopted here, the key question is not about the direction of the constitutional change, but rather whether a successful elimination of the term limit occurred or not. The latter option includes cases of Presidents who never publicly declared their intention to scrap their initial term limit as well as Presidents who attempted to do so but failed. (Baturo, 2010: 646). The rationale is to discern the differences between both sets of cases and thus inquire about the causes of eliminating term limits. Hence the dependent variable refers neither to any case of constitutional reform of the reelection rule (such as instituting a more restrictive rule or enabling a former president to run for a nonconsecutive term), nor to a decision by an outgoing president to run for a reelection.

For the present analysis, the sample of cases represents all elected Latin American presidencies between 1990 and 2013 where the Presidents served a full term ${ }^{6}$ and were barred from immediate reelection at the beginning of their original mandate. ${ }^{7}$ Therefore

5 I thank an anonymous reviewer for this point.

6 This excludes both Presidents who did not finish their full term due to death in office, resignation, ouster or non-elected Presidents who finished their terms. The rationale is to exclude Presidents unlikely to decide on reelection rule changes due to lack of popular mandate or a short stay in office.

7 The following 63 cases are included in the sample (only the year of assuming the presidency is listed, cases with a positive value of the dependent variable are in bold): Nicaragua 1997, 2002, 2007, Brazil 1995, 1999, 
only cases where Presidents had the opportunity to enact a more permissive reelection rule change are included in the analysis. The temporal selection rule includes presidents beginning those who were in office in 1990 and ending with those who completed their mandate by 2013.8

The discrete dependent variable measures whether such Presidents managed to do away with this term limit (" 1 ") or did not $\left({ }^{\prime \prime} 0\right.$ "). This leaves out cases of Presidents who could legally run for reelection already at the beginning of their first term (such as Lula da Silva in 2002), and the four cases where Presidents were eligible for immediate reelection but presided over a restrictive rule change that barred them from doing so. The sample only includes Presidencies that had ended by the end of 2013 (which excludes such cases of yet unfinished mandates where the intention or outright constitutional reform was announced to scrap term limits as in Bolivia by Evo Morales or Nicaragua by Daniel Ortega in 2013).

\section{Explanatory variables}

To operationalize the main explanatory variable -the degree of party institutionalizationthe (logged) Party age of the President's party at the time of the presidential election was used. This measure has become customary in analyses of party (system) institutionalization. Although party age represents only a rough measure of party institutionalization, its advantage consists in capturing many of the theoretical implications of the specified causal mechanisms. The perspective of the overlapping generations model is included insofar as members of old parties will expect the party to last, whereas members of young parties will doubt their party's durability (Stokes, 2001: 115). Correspondingly, the age of parties goes far in indicating the degree of their organizational complexity and adaptability as older parties are more likely to experience generational leadership changes away from the personalistic leadership of their founding fathers (Dix, 1992). The time dimension is implicit in the concept of party institutionalization as the party's survival as an institution implies its ability to adapt (Randall and Svåsand, 2002: 14). A natural logarithm of the number of years since party founding is used here to capture the notion that a given increase in party age (say 10 years) is a more substantial contribution to party institutionalization when the party is recently founded than when it has already endured for a century.

To capture the constraints and opportunities provided by the party system on the decision whether to evade term limits, we rely on an index of Party system fragmentation measured by the effective number of legislative parties (ENP) in the lower or only

2007, Argentina 1989, 1995, Peru 1990, 1995, 2001, 2006, Uruguay 1990, 1995, 2000, 2005, Paraguay 1993, 2003 , Bolivia 1989, 1993, 2006, Ecuador 1988, 1992, 2007, Panama 1994, 1999, 2004, Costa Rica 1990, 1994, 1998, 2002, 2006, Honduras 1990, 1994, 1998, 2002, El Salvador 1989, 1994, 1999, 2004, Guatemala 1986, 1996, 2000, 2004, 2008, Mexico 1988, 1994, 2000, 2006, Venezuela 1994, 1999, 2006 Colombia 1994, 1998, 2002, 2006 Chile 1990, 1994, 2000, 2006, Dominican Republic 1996, 2000, 2008.

8 The Panamian presidency of Guillermo Endara since 1989 is excluded because of the lack of data on the legislative composition. 
House during the President's mandate. The ENP values correspond to the concurrent or temporally most proximate legislative elections with the presidential election. The data were obtained from the OPAL database collected by the University of Salamanca (OPAL, 2014). To capture the operation of the mechanisms through which preexisting institutional configurations affect the likelihood of term limit elimination, a variable Reelection rule is constructed based on the coding of the extent to which reelection rules are restrictive or permissive at the beginning of the presidential term. This coding assigns the lowest value of (1) to rules prohibiting any reelection, (2) to reelection after two terms, (3) to reelection after one term, (4) to one consecutive reelection, and (5) to unlimited reelection (Negretto, 2013: 81). ${ }^{9}$

Table 1. Summary statistics

\begin{tabular}{lccccc}
\hline & $\begin{array}{c}\text { No. of } \\
\text { observations }\end{array}$ & Mean & $\begin{array}{c}\text { Standard } \\
\text { Deviation }\end{array}$ & Min & Max \\
\hline Party age (ln) & 63 & 3.17 & 1.39 & 0 & 5.10 \\
Party system fragmentation & 63 & 3.76 & 1.65 & 1.4 & 9.29 \\
Reelection rule & 63 & 2.27 & 1.09 & 1 & 4 \\
Executive constraints & 63 & 0.48 & 0.22 & 0.11 & 0.78 \\
Natural resources rents & 63 & 5.64 & 7.45 & 0.22 & 30.71 \\
(\% of GDP) & 63 & 51.49 & 5.31 & 40.08 & 60.48 \\
Economic inequality & 63 & 0.37 & 0.08 & .20 & 0.57 \\
Presidential Powers Index & 63 & 0.55 & 0.19 & .22 & 0.93 \\
Judicial independence & 29 & 0.49 & 0.19 & .12 & 0.85 \\
Presidential approval & & & & & \\
\hline
\end{tabular}

Two proxies are used to measure the stakes component of the actor-centered model of the reelection rule change. First, the Gini coefficient operationalizes the extent of Economic inequality in a given society. Second, the percentage share of rents accruing from natural resources on the GDP (Natural resources rents, \% of GDP) is used to measure the value of the presidential office more directly. This variable is based on the sum of rents from oil, natural gas, and coal as well as mineral rents and forest rents. The constraints component of the actor-centered model is operationalized with three measures that account for the elite-level checks on the executive. Executive constraints provides information about the extent of political discretion of the presidents. ${ }^{10}$ The index used here captures the feasibility of policy change given the number of independent branches of government and their political alignment with the president (Henisz, 2002: 363). The degree of Judicial independence is measured by an indicator created by Linzer and Staton (2011) as a latent

9 The data for this variable were collected from Negretto (2013: 254) and Zovatto and Orozco (2010: 193).

10 The polconv variable from the Political Constraint Index (Polcon) Dataset from the 2013 release is used (PCIPD, 2014). 
concept based on eight existing measures judicial of independence (Linzer, Staton 2011a). Its advantage is that the measure is suitable for time-series, cross-national comparisons and that is available for all country-years analyzed here in Latin America. ${ }^{11}$ Finally, the Presidential Powers Index is used to control for the effect of powerful presidents. The value of the index for each country in the sample was compiled from the scores calculated based on 35 different original variables drawn from different analyses of presidential powers (Doyle and Elgie, 2015a). ${ }^{12}$ The variable is again suitable for cross-section, timeseries analysis and the data is available for the whole time period.

Following Baturo (2010: 648), the values of all the economic variables represent the averages of the last three years of the president's tenure. If the presidential election took place during the second half of the year, the average was calculated from yearly data ending that year. If the election occurred in the first six months of the year, the calculation was lagged by one year. Data on all the economic variables was collected from the World Development Indicators database (WDI, 2014). The values of the Party age, Executive constraints, Reelection rule and Party system fragmentation variables are fixed at the first year of each respective President's tenure. To measure Presidential approval, percentage shares of those who approved of the President's performance were calculated from the comparative survey database with the most historical coverage in Latin America (Latinobarómetro 2015). ${ }^{13}$ Unfortunately, Latinobarómetro surveys have asked the question on presidential approval only since 2002 onwards. Only 29 Presidencies in the dataset can therefore be assigned a score on presidential approval which severely limits the number of available cases. ${ }^{14}$

Summary statistics for the independent variables are provided in Table 1.

\section{Model specification}

To test the aforementioned hypotheses, a logit regression model based on the 63 cases of Latin American presidencies is estimated. Robust standard errors clustered by country were used to control for correlation among observations in each country. The goal is to discern the magnitude of the effect of party institutionalization on the likelihood of eliminating term limits controlling for the variables drawn from the existing alternative theories.

11 The variable is measured on a 0 to 1 scale with higher values signifying more judicial independence. The mean values of the original variable averaged over the last three years of each presidency enter the analysis.

12 The prespow1 index is used here because it is advisable in Latin America where the range of standard errors on the estimated scores is smaller relative to scores (prespow2) calculated through the principal component analysis (see Doyle and Elgie, 2015a: 9).

13 A value of presidential approval averaged over the last three years of each presidency was calculated based on the responses to the following question: "Do you approve or disapprove the way the President (NAME OF PRESIDENT) is running the country?". Respondents reporting "Don't know" and "No response" were recoded as missing.

14 An alternative would be to also include results from other sources and national-level surveys for the earlier presidencies. However, this is not advisable due to issues of cross-national comparability, different survey standards and question wording. 
Table 2. Determinants of term limit removal

\begin{tabular}{|c|c|c|c|}
\hline & Model 1 & Model 2 & Model 3 \\
\hline Party age $(\ln )[-]$ & $\begin{array}{l}-0.81^{* * *} \\
(0.26)\end{array}$ & $\begin{array}{l}-0.86^{* *} \\
(0.39)\end{array}$ & $\begin{array}{l}-0.81^{* *} \\
(0.36)\end{array}$ \\
\hline Party system fragmentation [-] & & $\begin{array}{l}-0.18 \\
(0.26)\end{array}$ & \\
\hline Reelection rule $[+]$ & & $\begin{array}{c}0.49 \\
(0.42)\end{array}$ & \\
\hline Executive constraints [-] & & $\begin{array}{l}-1.09 \\
(1.93)\end{array}$ & \\
\hline $\begin{array}{l}\text { Natural resources rents }(\% \text { of GDP) } \\
{[+]}\end{array}$ & & $\begin{array}{l}0.11^{* *} \\
(0.05)\end{array}$ & \\
\hline Economic inequality $[+]$ & & $\begin{array}{l}-0.16^{*} \\
(0.09)\end{array}$ & \\
\hline Presidential Powers Index [+] & & $\begin{array}{l}13.41 \\
(8.52)\end{array}$ & \\
\hline Judicial independence [-] & & $\begin{array}{c}-11.33^{* *} \\
(4.44)\end{array}$ & \\
\hline Presidential approval [+] & & & $\begin{array}{l}4.09^{* *} \\
(1.97)\end{array}$ \\
\hline Constant & $\begin{array}{l}0.66 \\
(.81)\end{array}$ & $\begin{array}{c}8.66 \\
(5.81)\end{array}$ & $\begin{array}{l}-1.66 \\
(1.83)\end{array}$ \\
\hline Wald $\mathrm{Chi}^{2}$ & 9.85 & 46.55 & 16.63 \\
\hline Prob $>\mathrm{Chi}^{2}$ & 0.00 & 0.00 & 0.00 \\
\hline Pseudo $R^{2}$ & 0.19 & 0.45 & 0.26 \\
\hline Number of observations & 63 & 63 & 29 \\
\hline
\end{tabular}

Significant at ${ }^{* * *} \mathrm{p}<0.01 ;{ }^{* *} \mathrm{p}<0.05 ;{ }^{*} \mathrm{p}<0.1$.

Note: Signs in parentheses refer to the hypothesized direction of the coefficients. Robust standard errors clustered by country in parentheses.

Model 1 only includes the party institutionalization variable to test the plausibility of its impact, while model 2 also includes the explanatory variables as controls. Model 3 is estimated based only on the 29 cases of post-2002 presidencies where observations of the presidential approval were available. Only the two variables were included in this model because including all the controls returned a fully determined model. Considering the small number of cases and variables, the results of the Model 3 should be interpreted with caution. The hypothesized direction and significance of both variables suggests that both exercise an effect and that there is a discernible independent impact of party 
institutionalization even after controlling for the popularity of the President. This is an important finding giving support to the principal-agent model of term limit removal. An alternative suggestion is that more popular Presidents would strive for removing their term limit regardless of whether their party is institutionalized or not, and that more institutionalized parties would be equally likely to see their popular president remove the term limit (because this would increase their chances of winning the election). However, the results of Model 3 suggest otherwise: a popular President from a weakly institutionalized party is more likely to remove his/her term limit than a president with the same level of popularity but facing a strongly institutionalized party. Model 2 includes all the remaining controls. The coefficients on all the three variables operationalizing the constraints model point in the hypothesized direction, however, only Judicial independence reaches statistical significance. This is consistent with the argument that an independent judiciary insulated from political pressures poses a formidable constraint on the ability of presidents to remove their term limits. The coefficient for Executive constraints is significant only in a model that does not include the measure of party institutionalization (results not presented), but the magnitude of its effect declines sharply and becomes insignificant in model 2 after controlling for party institutionalization. This might suggest that party institutionalization is a more effective constraint. Of the economic variables, the coefficient for Economic inequality points in the opposite direction than predicted by the theory suggesting that overstaying the initial mandate due to a higher value of the presidential office in a more unequal society is not a satisfactory explanation in Latin America. The economic variable that exercises a consistent effect is the extent of the rentier economy. Presidents governing a country whose economy depends on rents from natural resources are significantly more likely to scrap term limits compared to presidents in economies which do not. This finding both provides further confirmation of the "oil-curse" theory of democracy (Ross, 2001), and supports the stakes-model through which the value of holding presidential office goes far in explaining how presidents manage to remove their initial term limits.

The coefficient on the main explanatory variable is highly significant and in the expected -negative- direction in all three models. Presidents from more institutionalized ruling parties are much less likely to scrap term limits than Presidents from recently created parties. The logit coefficients make it difficult to interpret the magnitude of the effect of party institutionalization directly. For ease of interpretation a simulation of the main quantities of interest from Model 2 was performed using the CLARIFY software (Tomz, Wittenberg and King, 2003). For this simulation all independent variables were held at their mean values except for the Reelection rule index where the median value $(3$, or the possibility of reelection only after one term) was used.

Figure 1 displays the probability of scrapping term limits across the whole range of the Party age variable. Keeping in mind that the natural logarithm of the number of years since the party founding was used in the model, the figure shows variation from the newly created one-year-old parties (a value of 0, such as the Peruvian Cambio 90 in 1990 or Primero Colombia in 2002 in the sample) to the oldest 164-year-old Uruguayan Colorado Party (value of 5.1). Ceteris paribus, there is on average a one in two (54.8\%) 
Figure 1. Impact of party institutionalization on the probability of presidential term limit removal

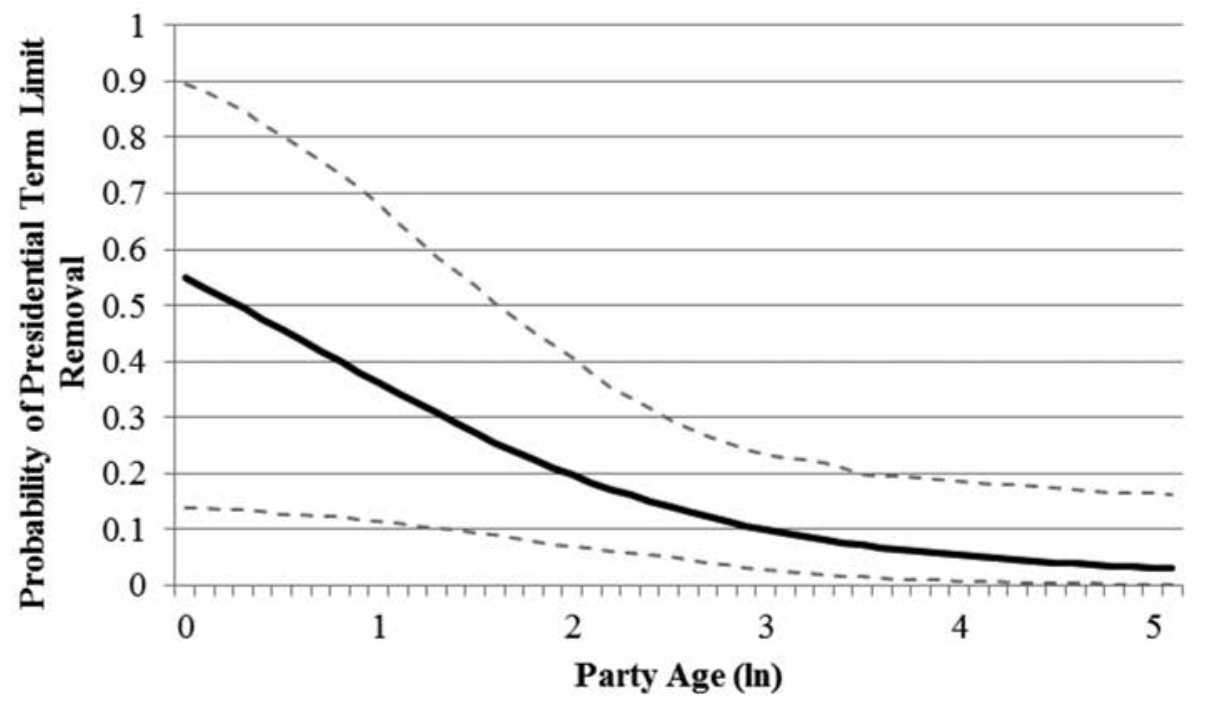

Note: Graph based on model 2. Grey lines represent the 95\% lower and upper confidence intervals. All other variables were held at their means, excepting Reelection rule for which the median value was set. CLARIFY software was used to produce the simulations (Tomz, Wittenberg and King, 2003).

probability that a president from a one-year old party will scrap term limits to allow his immediate reelection, but this probability declines to a mere $3 \%$ for the oldest party.

\section{QUALITATIVE ANALYSIS}

In order to test whether the observable implications of the theory stand to qualitative scrutiny, the operation of the causal mechanisms suggested by the theory are tested by case study evidence. To avoid the problem of selection on the dependent variable, cases are selected to reflect the variation on the outcome variable. First, only a single case of a successful attempt at making the reelection rules more permissive is briefly discussed to save space. The "extreme-case" of the Peruvian president Alberto Fujimori is selected. Extreme cases serve as paradigmatic instances of a phenomenon in that they exhibit a value on the distribution of a variable under study that is far from the mean (Gerring, 2007: 101). Fujimori's presidency is an extreme case in that it is only one of two cases (together with Venezuela's Hugo Chávez) where term limits were evaded twice, and also one of the two unusual cases (together with Nicaragua in 2009) where the possibility of re-reelection was pursued so vehemently that the term limit removal was accomplished with dubious legality. 
The sample of cases with an opposite value (an absence of reelection rule change) is harder to define because some Presidents do not consider manipulating term limits. Other Presidents may consider it but do not announce their intention publicly. Not considering or abandoning such a move may or may not be due to the causal factors implied by the theory. ${ }^{15}$ During the period under study, four instances of alleged or real attempts at term limit evasion that eventually did not succeed and where such moves sparked political controversy could be identified: Carlos Menem in 1998, Nicanor Duarte in 2006, Tabaré Vázquez in 2007/2008 and Manuel Zelaya in 2009. ${ }^{16}$ Examination of these four cases aims to provide corroborating evidence for the causal argument through pattern matching (Gerring, 2007: 45).

\section{Peru}

The Peruvian president Alberto Fujimori faced term limits both after his first term (1990-1995) and his second term (1995-2000), yet managed to evade both and to run for immediate reelections. Until 1993 Peruvian Presidents had been barred from seeking immediate reelection. Introducing the provision of a single consecutive reelection in the new constitution, Alberto Fujimori secured the possibility of running consecutively in 1995. However, by 1996 the Fujimori-dominated congress had already passed a controversial and unconstitutional "Law of Authentic Interpretation" that stipulated that the constitution cannot be applied retroactively, effectively decreeing that Fujimori's first term in office did not count for reelection purposes and therefore that he could run again in 2000 (Carrión, 2006: 142). The anti-reelectionist campaign united opposition and civil society groups which sought to organize a referendum on the issue. In spite of large popular support for holding the referendum, the possibility was eventually defeated by congress in 1998.

Promoting the two reelection rule changes, Fujimori had little opposition to face from his party. Throughout his presidency, he created as many as four political parties to contest different elections (Change 90 in 1990, New Majority in 1995, Let's go Neighbours in 1998 and Peru 2000 in 2000) which closely manifest the reversed principal-agent relationship. The platforms can be characterized as "disposable parties" or "electoral vehicles" (Sánchez, 2009: 513; Levitsky and Cameron, 2003: 11) Rather than creating a party of his own, Fujimori relied instead on personalistic linkages to his mass base. Refusing to invest into a party organization based on these disposable parties, Fujimori even actively impeded their consolidation and institutionalization (Levitsky and

15 Details of such decisions are sometimes only made public long after. Examples include the proposal of an immediate presidential reelection to allow the reelection of the Venezuelan president Carlos Andrés Pérez after his first term (1974-1979). The proposal was opposed by all the top leaders of the President's Acción Democrática party, eventually including the President himself (Coppedge, 1997: 171), giving support to the logic of intraparty competition blocking such moves within an institutionalized party.

16 There are two other instances where instituting immediate reelection was discussed but failed. Both Sixto Durán Ballén in Ecuador (1994) and Ernesto Pérez Balladares of Panama (1998) convened referenda that considered immediate presidential reelection. In the former case, the consultative referendum (marked by low participation) approved such a possibility but Congress later decided to retain the proscription on immediate reelection. 
Cameron, 2003: 10). All these parties remained extraordinarily weak and transient and subject to the decisions made by the undisputed leader who controlled their recruitment simply by choosing the candidates himself (Hinojosa, 2012: 113). The selection process for congressional candidates or top bureaucratic posts even involved screening the nominees through background checks, public opinion surveys or psychological interviews (Schmidt, 2006: 161). The weak non-institutionalized party structure and its complete lack of autonomy from the president precluded the possibility that his own party could hold the president to accounts by opposing his bid for eliminating term limits. In Latin American comparison, the extreme case of party system decomposition into candidatecentered parties in Peru during the 1990s (Levitsky and Cameron, 2003: 1) gave way to an extreme case of term limit manipulation.

\section{Argentina}

An unsuccessful bid for scrapping term limits occurred in Argentina during Carlos Menem's re-election attempt of 1997 and 1998. According to the 1994 constitution Menem was barred from seeking a third continuous term in office in 1999 but decided to find ways to challenge the prohibition. The case clearly demonstrates how intraparty dynamics function to block a more permissive presidential reelection rule change as the internal strength of his own party seems to have been the most important brake on Menem's attempt to extend his term limit (Corrales, 2009: 70). The President's own Partido Justicialista was the crucial actor that rejected the possibility of Menem's rereelection, causing a major conflict between the president and his party which viewed the attempt as an abusive act to perpetuate the personal power of Carlos Menem (De Luca, 2008: 210). Menem encountered a strong opposition within his own party because his potential third term threatened to block upward mobility opportunities for other PJ leaders (Corrales, 2010: 216). Menem's main rival from within the PJ, the governor of Buenos Aires Eduardo Duhalde, emerged as the leader of a large coalition of Peronists that sought to block Menem's re-reelection attempt which further escalated the conflict between the party and the executive.

The hostility between the executive and its own party became even more pronounced due to the re-reelection bid as crucial party leaders refused to attend a party congress and previously neutral party leaders began to join the anti-Menem camp (Corrales 2010: 216). In the end, the coalition of opposition parties and factions of Menem's Peronists led by Duhalde made it clear that they would block Menem's initiative to reform the constitution in the lower house (Helmke, 2003: 220). With a referendum on the issue out of the question due to the lack of popular approval, the only way to evade term limits for Menem was to defer the issue to the Supreme Court whose judges eventually refused to support Menem's bid, defecting from the president who had nominated them to their positions. Unlike in personalistic presidentialized parties where the party organization is subordinated to the president, Peronists during the Menem era could best be characterized by a relationship of "mutual autonomy" between the presidency and the party rank and file (Levitsky, 2003: 177). Menem had little influence over the traditional local and provincial party branches that delivered much of the vote through 
party machines and which successfully resisted Menem's imposition of candidates and political strategies. This intraparty autonomy became a crucial source of the failure by the president to evade term limits.

\section{Honduras}

The military ouster of the Honduran president Manuel Zelaya in 2009 presents the culmination of another case of unsuccessful term limit manipulation, although Zelaya himself rejected the idea that his push for constitutional reform was motivated by seeking future reelection (Ginsburg et al., 2011: 1810). The fear that a future Constituent Assembly sought by Zelaya would eliminate the absolute proscription on reelection became the central argument made by his opponents in justifying Zelaya's ouster. The roots of the political crisis, however, lie deeper in the policy switch against his initial political stance and his own political party that Zelaya carried out during the three years of his presidency (Cunha Filho et al., 2013). The policy switch was unique in that it entailed a right-to-left move unlike most other such betrayals of mandates in Latin America that have evolved in the opposite direction. Originally campaigning on a rightof-center party platform, Zelaya gradually shifted to contrary policies such as larger state intervention in the crucial energy sector, and eventually entering the chavista platforms of Petrocaribe and ALBA (Cunha Filho et al., 2013).

A characteristic feature of Zelaya's Partido Liberal de Honduras (PLH) was its deep factionalism. The common PLH label provided structure for conflicts among opposing factions that crystallized around powerful figures rather than programmatic issues. The intraparty conflicts were resolved by informal power-sharing pacts involving the distribution of state resources that both provided stability to the party and prevented the transformation of these factions into alternative parties (Otero, 2013: 256). As a consequence of both a new electoral system of open party lists and the deep party factionalization the presidential candidate had very little control over the selection of PLH deputies from other factions who consequently were freer to act autonomously from the presidential leadership (Battle, 2008: 145). These internal party differences came to light before the 2008 primary elections with an ensuing conflict between the president and the strongest faction led by a possible PLH precandidate, the president of the Honduran Congress Roberto Micheletti (Peetz, 2009: 183). For a time, these intraparty differences in terms of candidate selection and policy were contained as Micheletti received Zelaya's support in the November 2008 presidential primaries in exchange for delivering congressional consent to important laws, such as the entry to ALBA by PLH deputies. Losing the primaries to the vice-president Elvin Santos, however, left Micheletti with few incentives to cooperate with the president (Cunha Filho et al., 2013: 525). During 2009, Zelaya found himself facing a hostile congress led by powerful factions of his own party. The events leading to Zelaya's kidnaping by the military on 28 June were triggered by the opposition of most of the PLH and the PNH to his push for a consultative referendum whether to hold a popular referendum to convene a Constituent Assembly. After Zelaya's ouster, Roberto Micheletti was sworn in by the Congress as President. 
Much of the dynamics of the political crisis can be traced to intraparty competition within an institutionalized party. The traditional Honduran two-party party system had been one of the most stable and institutionalized by the time of Zelaya's presidency. The two principal parties, PLH and Partido Nacional de Honduras (PNH) competed in a closed system, rotated the presidency and diverged little in terms of their rightof-center policy positions. Similar to the Argentine Partido Justicialista discussed earlier, the party organization of the PLH was largely autonomous from the President and powerful enough to challenge him. According to a 2006 survey among Honduran legislators their own nomination as legislative candidates was only marginally influenced by national leaders as almost $90 \%$ of them acknowledged being selected by local internal primaries, and only $9.3 \%$ by national leadership (Battle, 2008: 135). Yet internal party organization mattered a great deal for the selection of candidates and power balance within the party. By the time of the election of Zelaya, the PLH had become a deeply factionalized party with factions tied less to ideological differences than to the political aspirations of local caudillos (Battle, 2008: 137). Institutionalization of the PLH meant the presence of both powerful veto players within the party and politicians with viable chances to compete in presidential elections. As the relationship between Micheletti and Zelaya illustrates, the fragile balance of power and personal ambitions within the party could have been easily put in danger had presidential reelection been instituted.

While policy switching is unlikely and infrequent with institutionalized parties (Stokes, 2001: 118), the Honduran case suggests that when it happens in such traditional parties, the intraparty opposition may overwhelm the President and trigger anti-democratic outcomes. Institutionalized parties, such as the PLH, possess a wide range of means of reining in their presidential agents both in terms of policy and (perceived) term limit evasion. Though not possible to discuss in detail, the case resembles a failed attempt at term limit evasion in another traditional party, the Paraguayan Colorado Party. In 2004, less than a year into his mandate the Colorado president Nicanor Duarte announced his proposal to allow himself immediate presidential reelection through convening a Constituent Assembly and later through other means. Characterized by deep internal divisions and bitter infighting among party factions ("clans") (Rouquié, 2011: 158), the party's Presidents have been confronted with powerful and autonomous intraparty veto players which have limited their ability to control their party and weakened their position vis-à-vis the Congress (Molinas et al., 2004: 74). Not surprisingly, much of the intraparty opposition to Duarte's reelection bid came from deputies and senators not associated with Duarte's party faction who feared for their future political careers $(A B C, 2006)$.

\section{Uruguay}

Although Uruguay's Tabaré Vázquez never openly announced his support for his immediate reelection, the issue occupied central stage of his mandate for several years. In 2007, Vázquez himself emphasized that he would not accept nomination for reelection (TeleSUR, 2008). However, factions of the Frente Amplio started a reelectionist campaign 
attempting to gather enough signatures to convene a referendum that would change the constitutional provision prohibiting immediate reelection. Several high-ranking politicians including ministers of the Vázquez government supported the initiative while other sectors of the Frente Amplio openly opposed it. The high approval numbers of the President and a sizable popular support for his reelection turned the issue into a sensitive political topic. The persistence of the campaign was also justified by its leaders on the grounds that Vázquez himself had not said the last word on the matter (BBC, 2008). With ambiguous messages from the administration, the anti-reelectionist Frente Amplio leaders argued that Vázquez had remained secretly behind the campaign to allow his reelection (Terra, 2008a).

Much of the Socialist Party of president Vázquez supported the reelection, but other party factions eventually began supporting other precandidates for the party primaries, highlighting the fragmentation both within the presidential party and the governing coalition (Terra, 2008b). For example, José "Pepe" Mujica's position on the issue evolved over time probably reflecting his pre-candidacy to run as a presidential candidate of the Frente Amplio. In early 2007, Mujica claimed that the reelection of Vázquez is an "ideal solution" because it would reduce internal disputes (VCM, 2007). By the end of 2008, Mujica positioned himself against the reelection claiming that the issue was detrimental to Frente Amplio unity (Terra, 2008a). In the end, the reelectionst campaign ended in March 2009 after gathering only 100 thousand signatures, far short of the quarter million signatures necessary to convene the referendum.

The Uruguayan case illustrates how the issue of term limit evasion is approached by a relatively institutionalized party with a diffuse organizational structure composed of often conflicting factions and parties. The internal power balance of such a coalition would have been shifted radically in favor of the presidential party had term limits been lifted. It was the Frente Amplio's organizational autonomy that served as a brake on such attempts as the president was unable (and perhaps unwilling) to impose his will regarding reelection on his own party. Being able to generate other viable presidential candidates who have the most to lose from scrapping term limits, party institutionalization served as a reliable brake on a more permissive reelection rule change.

\section{DISCUSSION AND CONCLUSIONS}

Both quantitative and qualitative evidence presented here suggests the importance of intraparty politics on the decision (not) to evade presidential term limits. In particular, doing away with term limits is substantially more likely if the presidential party is not institutionalized. Contrarily, institutionalized parties prevent their presidents from removing bans on their immediate reelection. This association is robust even after considering other potential causes of term limit rules change, such as the type of preexisting constitutional rules governing reelection, the extent of the rentier economy presided over by the President, or the executive constraints faced by the Presidents. The qualitative evidence highlights the importance of such features of institutionalized parties as the 
sufficient supply of other political leaders capable of running for presidential election whose upward mobility would be put to risk by reelection, the presence of powerful intraparty veto-players with a stake in not allowing reelection, or the autonomy of party organizations on the decisions of their presidents. This contrasts with situations in which presidential parties are hardly autonomous of their Presidents. These personalistic parties or platforms cannot serve as effective brakes on the decision to evade term limits. The adoption of constitutional rules favoring personalistic political competition is associated with the emergence of personalistic parties.

The argument challenges the view that parties operating in presidential regimes may not serve as effective principals of their president-agents. Considering and distinguishing different party types within the principal-agent theoretical framework may be a fruitful way of considering also other political outcomes where delegation is involved. The argument has important implications for the literature that views Latin American constitutional change in general and electoral rule change in particular as endogenous products of interparty competition (Negretto, 2006; Remmer, 2008; Wills-Otero, 2009). By emphasizing the role of intraparty politics instead, it may be possible to focus on the more proximate factors behind the constitutional reforms in Latin America. At least for the case of re-election rule change it seems that the intraparty balance of power is a more decisive force than the distribution of power within the party system. Perhaps re-election rules are unique in that they have direct implications for the quality of democracy: as the anti-reelectionists argue, the absence of term limits outbalances the system of checks and balances in favor of the President and weakens democratic institutions. Seen from this perspective, it is fully appropriate then to consider intraparty norms and rules, rather than the interparty balance of power, as the crucial source behind the success of the system of checks and balances in preventing tyranny (Samuels and Shugart, 2010: 254). To the extent that the internal balance of power within institutionalized parties keeps Presidents from evading term limits, it also contributes to the operation of the system checks and balances.

Political parties are central to democratic political competition because they fulfill important functions ranging from interest aggregation and articulation to elite socialization. Functional political parties also serve as checks and balances on the omnipotence of executive authority. By standing above parties and being unaccountable to them and other political institutions, delegative presidencies that have sprung up in many Latin American countries present a risk to democratic development (O'Donnell, 1994). By being able to block the striving of their Presidents for reelection, stronger and more autonomous parties may offer a partial antidote to feeble assemblies and unchecked executive power that characterize many new democracies (VonDoepp, 2005: 66). Such an aspect of the system of checks and balances is missing in underinstitutionalized party systems. In these settings where Presidents also run for and win reelection a premium is put on delegative leadership styles where the direct vertical accountability between the president and his popular following outmaneuvers all other forms accountability. In underinstitutionalized party system settings with permissive reelection rules, delegative democracies arise and prosper. Their Presidents are allowed to escape one of the few 
constraints that G. O'Donnell (1994) stipulated to check the power of such presidents: the constitutionally limited period of their mandates.

Some have advocated the middle solution between the proscription on immediate reelection and the absence of any term limits: allowing presidents a single immediate reelection. This has indeed been the principal rule adopted by reelection seekers. Yet the Latin American experience suggests that this initial rule, once inaugurated, does not become institutionalized: already more permissive reelection rules invite their further undoing. Re-election seekers are recidivists who are likely to seek another term. Of the eight two-term Presidents who changed the reelections rules in their favor, for two of them it is too early to judge whether they will strive for further reelection beyond the initial change (Daniel Ortega and Rafael Correa), although passing the constitutional reform that allows for unlimited re-election by Nicaragua's Daniel Ortega in 2014 strongly suggests his intention to run for a third consecutive term. Of the remaining six, only one (Cardoso) did not attempt a second re-election, while five of them did. Carlos Menem and Álvaro Uribe did not succeed in their striving for re-reelection, while Hugo Chávez, Alberto Fujimori and Evo Morales did (the two latter ones with dubious legality).

Perhaps the key argument of the opponents of term limits is that the possibility of reelection flexibilizes the political process by strengthening the accountability of the sitting presidents. Removing the possibility of re-election may indeed weaken the accountability of the President vis-à-vis his/her voters but even when immediate reelection is banned "voters can still hold the President's party accountable" (Mainwaring and Shugart, 1997: 461). This implies that parties can serve as alternative agents of accountability even if their presidents may not due to term limits. Even in the presence of term limits, voters may punish governing parties for their performance. Yet persistent party system instability marked by the emergence of newly created parties and the disappearance of old ones substantially reduces democratic accountability: voters cannot "throw the rascals out" if the rascals no longer exist (Birch, 2003: 120). The association between noninstitutionalized parties and reelectionism does not bode well for democratic accountability: it erases both the accountability relationship between voters and parties, and between parties and their officeholders. All that remains is the "vertical accountability" of the President to his/her voters.

\section{REFERENCES}

Alesina, Alberto and Spear, Stephen E. 1988. "An overlapping generations model of electoral competition". Journal of Public Economics 37 (3): 359-379.

Battle, Margarita C. 2008. "La dinastía liberal: la selección de los candidatos a diputados en el Partido Liberal de Honduras en 2005". Annals of the Ovidius University Constanta - History Series 5: 123-150.

Baturo, Alexander. 2010. "The Stakes of Losing Office, Term Limits and Democracy". British Journal of Political Science 40: 635-662.

Beller, Dennis C. and Belloni, Frank P. 1978. "Party and Faction: Modes of Political Competition". In Faction Politics: Political Parties and Factionalism in Comparative Perspective edited by Frank Belloni and Dennis Beller. Oxford: ABC-Clio, 417-50. 
Birch, Sarah. 2003. Electoral Systems and Political Transformation in Post-Communist Europe. London: Palgrave MacMillan.

Boucek, Francoise. 2009. "Rethinking Factionalism Typologies, Intra-Party Dynamics and Three Faces of Factionalism". Party Politics 15 (4): 455-485.

Buquet, Daniel. 2007. “Entre la legitimidad y la eficacia: reformas en los sistemas de elección en América Latina". Revista Uruguaya de Ciencia Política 16: 35-49.

Carey, John. 2003. "The Reelection Debate in Latin America". Latin American Politics and Society 45 (1): 119-133.

Carrión, Julio. 2006. The Fujimori Legacy: the rise of electoral authoritarianism in Peru. The Pennsylvania State University Press.

Coppedge, Michael. 1997. Strong parties and lame ducks: presidential partyarchy and factionalism in Venezuela. Stanford: Stanford University Press.

Corrales, Javier. 2008. “Latin America's Neocaudillismo: Ex-Presidents and Newcomers Running for President... and Winning". Latin American Politics and Society 50 (3): 1-35.

2009. "Volatilidad económica, debilidad de partidos y el neocaudillismo en América Latina". Journal of Democracy 1: 55-76.

2010. Presidents without parties: the politics of economic reform in Argentina and Venezuela in the 1990s. Penn State Press.

Corrales, Javier and Penfold, Michael. 2014. "Manipulating Term Limits in Latin America". Journal of Democracy 25 (4): 157-168.

Cunha Filho, Clayton M., André Luiz Coelho and Pérez Flores, Fidel I. 2013. "A right-to-left policy switch? An analysis of the Honduran case under Manuel Zelaya". International Political Science Review 34 (5): 519-542.

Dix, Robert H. 1992. "Democratization and the institutionalization of Latin American political parties". Comparative Political Studies 24 (4): 488-511.

De Luca, Miguel. 2008. "Political Recruitment and Candidate Selection in Argentina: Presidents and Governors, 1983 to 2006". In Pathways to Power Political Recruitment and Candidate Selection in Latin America, edited by Peter Siavelis and Scott Morgenstern. University Park: The Pennsylvania State University Press, 189-217.

Del Campo, Esther. 2009. Reelección presidencial y rendición de cuentas: ¿De verdad es tan mala la reelección? Madrid: Fundación Carolina.

Doyle, David and Elgie, Robert. 2015a. "Maximizing the Reliability of Cross-National Measures of Presidential Power". British Journal of Political Science FirstView Article, 1-11.

Gerring, John. 2007. Case Study Research. Principles and Practices. Cambridge: Cambridge University Press.

Ginsburg, Tom; Melton, James and Elkins, Zachary. 2011. "On the Evasion of Executive Term Limits". William and Mary Law Review 52: 1807- 1872.

Guliyev, Farid. 2009. "End of Term Limits: Monarchical Presidencies on the Rise". Harvard International Review, February (28).

Helmke, Gretchen. 2003. "Checks and Balances by Other Means: Strategic Defection and Argentina's Supreme Court in the 1990s". Comparative Politics 35 (2): 213-230.

Henisz, Witold. 2002. "The Institutional Environment for Infrastructure Investment". Industrial and Corporate Change 11 (2): 355-89.

Hinojosa, Magda. 2012. Selecting Women, Electing Women: Political Representation and Candidate Selection in Latin America. Philadelphia: Temple University Press.

Huntington, Samuel. 1968. Political Order in Changing Societies. New Haven: Yale University Press.

Janda, Kenneth. 1980. Political Parties: A Cross National Survey. New York: Free Press.

Tomz, Michael; Wittenberg, Jason and King, Gary. 2003. “CLARIFY: Software for interpreting and presenting statistical results". Journal of Statistical Software 8 (1): 1-30.

Levitsky, Steven. 2003. Transforming Labor-Based Parties in Latin America. Argentine Peronism in Comparative Perspective. Cambridge: Cambridge University Press.

Levitsky, Steven and Cameron, Maxwell. 2003. "Democracy without Parties? Political Parties and Regime Change in Fujimori's Peru". Latin American Politics and Society 45 (3): 1-33. 
Linz, Juan J. 1994. "Presidential or Parliamentary Democracy: Does It Make a Difference?". In The Failure of Presidential Democracy, edited by Juan J. Linz and Arturo Valenzuela. Baltimore: The John Hopkins University Press, 3-87.

Linzer, Drew A. and Staton, Jeffrey K. 2011a. "A measurement model for synthesizing multiple comparative indicators: The case of judicial independence". In Presentation at the 2011 Annual Meeting of the American Political Science Association, 1-42.

Mainwaring, Scott and Shugart, Matthew S. 1997. "Juan Linz, Presidentialism, and Democracy: A Critical Appraisal". Comparative Politics 29 (4): 449-471.

Mainwaring, Scott and Torcal, Mariano. 2006. "Party system institutionalization and party system theory after the third wave of democratization". In Handbook of party politics, edited by Richard Katz and William Crotty. Sage Publications, 204-227.

Martínez-Barahona, Elena. 2012. "Constitutional Courts and Constitutional Change: Analysing the Cases of Presidential Re-Election in Latin America". In New Constitutionalism in Latin America, edited by Detlef Nolte and Almut Schilling-Vacaflor. Burlington: Ashgate, 289-312.

Molina, JoséE. 2009. “La reforma informal del sistema electoral venezolano: de la representación proporcional al sistema mayoritario sin alterar una coma". In Reforma del Sistema Electoral Chileno, edited by Arturo Fontaine, Cristián Larroulet, Jorge Navarrete and Ignacio Walker. Santiago: PNUD, 139-164.

Molina, José; Pérez-Liñán, Aníbal and Saiegh, Sebastián. 2004. "Political Institutions, Policymaking Processes, and Policy Outcomes in Paraguay, 1954-2003". Revista de Ciencia Política (Santiago) 24 (2): 67-93.

Moreno, Erika; Crisp, Brian F. and Shugart, Matthew S. 2003. "The Accountability Deficit in Latin America". En Democratic Accountability in Latin America, edited by Scott Mainwaring and Christopher Welna. Oxford University Press, 79-131.

Negretto, Gabriel. 2006. "Choosing how to choose presidents: Parties, military rulers, and presidential elections in Latin America". Journal of Politics 68 (2): 421-433.

2013. Making Constitutions. Presidents, Parties, and Institutional Choice in Latin America. New York: Cambridge University Press.

O’Donnell, Guillermo. 1994. “Delegative Democracy". Journal of Democracy 5 (1): 55-69.

Otero, Patricia. 2013. "El sistema de partidos de Honduras tras la crisis política de 2009. ¿El fin del bipartidismo?". Colombia Internacional 79: 249-287.

Peetz, Peter. 2009. “¿De hacendado a revolucionario? Mel Zelaya y el giro hacia la izquierda del gobierno hondureño". Iberoamericana 33 (9): 181- 186.

Penfold, Michael; Corrales, Javier y Hernández, Gonzalo. 2014. “Los Invencibles: La reelección presidencial y los cambios constitucionales en América Latina". Revista Ciencia Política 34 (3): 537-559.

Randall, Vicky and Svåsand, Lars. 2002. "Party institutionalization in new democracies". Party politics 8 (1): 5-29.

Remmer, Karen L. 2008. “The Politics of Institutional Change: Electoral Reform in Latin America, 19782002". Party Politics 14 (1): 5-30.

Roberts, Kenneth M. 2012. "Parties, Party Systems, and Political Representation". In Routledge Hanbook of Latin American Politics, edited by Peter Kingstone and Deborah Yashar. New York: Routledge, 48-60.

Ross, Michael L. 2001. "Does Oil Hinder Democracy?". World Politics 53 (3): 325-361.

Rouquié, Alain. 2011. A la sombra de las dictaduras. La democracia en América Latina. Buenos Aires: Fondo de Cultura Económica de Argentina.

Samuels, David J. and Shugart, Matthew S. 2010. Presidents, parties, and prime ministers: how the separation of powers affects party organization and behavior. Cambridge: Cambridge University Press.

Sanchez, Omar. 2009. "Party Non-Systems A Conceptual Innovation“. Party Politics 15 (4): 487-520.

Schmidt, Gregory D. 2006. "All the President's Women: Fujimori and Gender Equity in Peruvian Politics". In The Fujimori Legacy: The Rise of Electoral Authoritarianism in Peru, edited by Julio Carrión. University Park: Penn State Press, 150-77.

Stokes, Susan. 2001. Mandates and Democracy: Neoliberalism by Surprise in Latin America. New York: Cambridge University Press.

VonDoepp, Peter. 2005. "Party cohesion and fractionalization in new African democracies: Lessons from struggles over third-term amendments". Studies in Comparative International Development 40 (3): 65-87. 
Wills-Otero, Laura. 2009. "Electoral Systems in Latin America: Explaining the Adoption of Proportional Representation Systems During the Twentieth Century". Latin American Politics and Society 59 (3): 33-58.

Zovatto, Daniel and Orozco. Jesús J. 2010. "Reforma política y electoral en América Latina 1978-2007: lectura regional comparada". In Reforma política y electoral en América Latina, edited by Daniel Zovatto and Jesús Orozco. Stockholm: IDEA, 3-213.

\section{News sources and databases}

$A B C$. 2006. "Senadores que no integrarán próxima lista colorada se niegan a hablar de reelección" (September 3). In: http://archivo.abc.com.py/2006-09-03/articulos/276457/senadores-que-nointegraran -proxima-lista-colorada-se-niegan-a-hablar-de-reeleccion

Terra. 2008. "Líderes oficialistas arremeten contra la campaña de reelección de Tabaré Vázquez" (November 6). In: http://noticias.terra.es/2008/mundo/1106/actualidad/lideres-oficialistas-arremeten-contrala-campana-de-reeleccion-de-tabare-vazquez.aspx

Terra. 2008. “Vázquez dice que no buscará la reelección y trata de restablecer la unidad" (November 7). In: http:// noticias.terra.es/2008/mundo/1107/actualidad/vazquez-dice-que-no-buscara-la-reeleccion-y-tratade-restablecer-la-unidad.aspx

BBC. 2008. “Uruguay: buscan reelección de Vázquez" (September 4). In: http://news.bbc.co.uk/hi/ spanish/latin_america/newsid_7598000/7598751.stm

TeleSUR. 2008. "Reelección de Tabaré Vázquez genera debate entre fuerzas políticas" (January 18). In: http:/ / exwebserv.telesurtv.net/secciones/noticias/23346-NN/reeleccion-de-tabare-vazquez -genera-debate-entre-fuerzas-politicas-uruguayas/

VCM. 2007. "El Frente Amplio debate la reelección de Tabaré Vázquez" (May 15). In: http:/ /vamosacambiarelmundo. org/2007/05/el-frente-amplio-debate-la-reeleccion-de-tabare-vazquez/

\section{Databases}

Linzer, Drew A. and Staton, Jeffrey K. 2011b. "Latent Judicial Independence around the Globe, 1948-2010". In: http://polisci.emory.edu/faculty/jkstato/page3/index.html

Doyle, David and Elgie, Robert. 2015b, "Maximizing the Reliability of Cross-National Measures of Presidential Power". In: http://dx.doi.org/10.7910/DVN/28939, Harvard Dataverse, V2.

Latinobarómetro. 2015. “Latinobarómetro surveys (2002-2013)". Corporación Latinobarómetro. In: http: //latinobarometro.org/

OPAL 2014. Observatorio de partidos politics de América Latina. Instituto de Iberoamérica de la Universidad de Salamanca. In: http://americo.usal.es/oir/opal/indicadores.htm

WDI 2014. World Development Indicators. World Bank. In: http://data.worldbank.org/data-catalog/ world-development-indicators

PCIPD 2014. Political Constraint Index (Polcon) Dataset. In: http://mgmt5.wharton.upenn.edu/henisz/_ vti_bin/shtml.dll/POLCON/ContactInfo.html

Karel Kouba is assistant professor of political science at the Department of Politics of the University of Hradec Králové (Czech Republic). He received his MA at Miami University and PhD at Palacky University. His research focuses on voting behavior and electoral systems in Latin America and post-communist Europe. E-mail: karel.kouba@uhk.cz. 
